\title{
Fluorescence characteristics of humic-like fluorescent dissolved organic matter produced by various taxa of marine bacteria
}

\author{
Koichi Shimotori ${ }^{1,3}$, Keiji Watanabe ${ }^{2}$, Takeo Hama ${ }^{1, *}$ \\ ${ }^{1}$ Graduate School of Life and Environmental Sciences, University of Tsukuba, Tsukuba, Ibaraki 3058572, Japan \\ ${ }^{2}$ Water and Soil Environment Division, National Institute for Environmental Studies, Tsukuba, Ibaraki 3058506, Japan \\ ${ }^{3}$ Present address: Research Facility Center for Science and Technology, University of Tsukuba, Ibaraki 3058577, Japan
}

\begin{abstract}
An experimental study was conducted to assess the difference in humic-like fluorescence characteristics (excitation/emission $=290$ to $360 / 370$ to $460 \mathrm{~nm}$ ) of dissolved organic matter produced by bacteria isolated from coastal seawater. Ten bacterial strains were isolated, and 1 additional strain was obtained from the Japan Collection of Microorganisms. The strains' nearest phylogenetic neighbors were identified using 16S rRNA gene analysis. Eleven bacterial strains were inoculated in experimental liquid medium and incubated for $7 \mathrm{~d}$. In this incubation experiment, the excitation-emission matrixes of the culture media were analyzed to elucidate the production of humic-like fluorescent dissolved organic matter (FDOM) between Day 0 and Day 7 of the incubation. The production of humic-like FDOM was found in 8 of the 11 culture media, with a total of 14 humic-like fluorescence peaks detected. Of these peaks, 10 exhibited different fluorescence characteristics. These findings indicate that the fluorescence characteristics of bacterialderived humic-like FDOM differed among the bacterial groups. Several cultures of bacterial strains contained FDOM, with peaks occurring in the spectral region often associated with humiclike material of terrestrial origin. One bacterial strain showed productivity of humic-like FDOM that was 1 order of magnitude higher than most of the bacterial strains. This result implies that the relative importance of humic-like FDOM production is different among bacterial genera in the ocean.
\end{abstract}

KEY WORDS: Fluorescent dissolved organic matter - Bacteria - Excitation-emission matrix · Spectroscopy Resale or republication not permitted without written consent of the publisher

\section{INTRODUCTION}

Oceanic dissolved organic matter (DOM) is one of the largest carbon reservoirs of the surface layer of the earth (Hedges 1992) and plays a central role in oceanic ecosystems (Carlson 2002). Most oceanic DOM is refractory DOM (R-DOM) and persists in the ocean for more than several centuries (Williams \& Druffel 1987). However, a considerable amount of DOM that is supplied autochthonously by primary producers, i.e. phytoplankton, has a short turnover time (Bertilsson \& Jones 2003). Thus, the transformation processes from labile DOM to R-DOM have been studied. Recent studies indicate that bacterial metabolism (Ogawa et al. 2001, Hama et al. 2004) and photochemical reactions (Obernosterer et al. 1999) transform labile DOM to R-DOM. Although several R-DOM production processes have been discovered, the characterization of R-DOM using traditional chemical analysis is not easy due to the difficulty of isolating pure material and the low concentration of oceanic DOM (Benner 2002, Mopper et al. 2007). 
Hence, various approaches to elucidate the nature of R-DOM have been developed.

Fluorescent DOM (FDOM) has been commonly observed in oceanic environments and is considered one of the major fractions of R-DOM (Yamashita \& Tanoue 2008). In oceanic environments, excitationemission matrix (EEM) spectroscopy, in which a 3dimensional contouring intensity landscape appears as a fingerprint with high sensitivity, has been widely used to obtain qualitative and quantitative information on FDOM (Coble 1996, Parlanti et al. 2000). Based on EEM spectroscopy, FDOM is roughly classified into 2 components: one protein-like and the other humic-like (Coble 1996). Both components have been routinely further divided into several subdivisions: tyrosine-like and tryptophan-like fluorescence for protein-like FDOM and visible, marine and UV humic-like fluorescence for humic-like FDOM (Coble 1996).

In coastal regions, terrestrial inflow of FDOM is one of the dominant sources of oceanic FDOM. A negative correlation between humic-like FDOM and salinity (Blough \& Del Vecchio 2002, Yamashita \& Tanoue 2004) suggests that the distribution of humic-like FDOM is significantly influenced by the inflow of humic-like FDOM of terrestrial origin. A spectral fluorescence signature often associated with terrestrial humic-like fluorescence has been observed in coastal regions (Stedmon et al. 2003, Murphy et al. 2008, Yamashita et al. 2008). Autochthonous production of FDOM is also important. Shimotori et al. (2009) demonstrated that bacteria produce humic-like FDOM with characteristics comparable with oceanic R-DOM. Additionally, measurements of the vertical distribution of humic-like FDOM in marine environments showed that oceanic humic-like FDOM has a positive relationship with inorganic nutrient concentration and apparent oxygen utilization (Hayase \& Shinozuka 1995, Yamashita et al. 2007). These findings suggest that microbes, especially bacteria, have a significant role as producers of oceanic humic-like FDOM.

Humic-like FDOM is commonly observed in the ocean. However, the fluorescence characteristics of oceanic humic-like FDOM show variability depending on the sampling site and production source (Stedmon et al. 2003, Murphy et al. 2008). It is known that the variations of fluorescence characteristics are partly due to the photochemical reactions (Vähätalo $\&$ Wetzel 2004) and microbial consumption (Moran et al. 2000) of FDOM. However, the influence of marine bacterial phylogenetics has not been considered in relation to the different fluorescence characteristics of FDOM.
Bacterial-derived FDOM has been considered as one uniform component, to date. However, various bacterial phylogenetic groups inhabit the ocean, and their metabolic systems differ (Nealson 1999). Thus, bacterial metabolic products may vary depending on their metabolism. Several studies have shown that the utilization of dissolved organic components by bacteria differ across the major phylogenetic groups (e.g. Cottrell \& Kirchman 2000, Alonso \& Pernthaler 2006). These findings imply that the relative importance and contribution of bacteria to the production of humic-like FDOM may be different among bacterial groups. Moreover, there is a possibility that the fluorescence characteristics of bacteria-derived humiclike FDOM (BAC-humic-like FDOM) relate to bacterial phylogenetic groups. Nevertheless, little attention has been given to the individual role of a bacterial strain in the production of humic-like FDOM.

In this study, bacterial strains were isolated from coastal seawater, and each bacterial genus was identified based on $16 \mathrm{~S}$ ribosomal ribonucleic acid (rRNA) gene analysis. The bacterial strains were inoculated in Marine Broth 2216 (Difco) liquid medium and incubated for $7 \mathrm{~d}$. In this incubation experiment, the EEMs of the culture medium were analyzed to assess the differences in BAC-humic-like FDOM production among oceanic bacterial groups. The DOC and POC concentrations of the culture medium were also measured to estimate the difference in the capacity for FDOM productivity among bacterial strains.

\section{MATERIALS AND METHODS}

\section{Sample collection}

Surface seawater was collected from Oura Bay $\left(34^{\circ}\right.$ $\left.39^{\prime} 50.5^{\prime \prime} \mathrm{N}, 138^{\circ} 56^{\prime} 30.1^{\prime \prime} \mathrm{E}\right)$ on 12 January 2007 and 19 August 2008 and from Nabeta Bay (34 39' 55.3" N, $138^{\circ} 56^{\prime} 13.0^{\prime \prime} \mathrm{E}$ ) on 20 November 2008. These bays are both located in Shimoda, Shizuoka, Japan. These sampling sites were chosen to obtain bacterial strains from different environments. Sterile $500 \mathrm{ml}$ polycarbonate bottles were filled with surface seawater and stored for less than $36 \mathrm{~h}$ at $4{ }^{\circ} \mathrm{C}$ until filtration. The water samples were filtered through glass fiber filters (GF/F, Whatman) in a laminar flow cabinet to remove the particulate matter, including zooplankton and phytoplankton. The resultant filtrate was used as the bacterial inocula. The filtrate of Nabeta Bay seawater was also used as an inoculum representing a natural bacterial assemblage in a humic-like FDOM production experiment. 


\section{Preparation of medium, bacterial isolation and cultivation of bacteria}

Two isolation media were prepared, a Marine Broth 2216 and a seaweed medium. The former medium was prepared by dissolving $37.4 \mathrm{~g}$ of Marine Broth 2216 in 11 of Milli-Q water. The seaweed liquid medium was prepared as follows: (1) $100 \mathrm{~g}$ (wet weight) of the fresh seaweed, Ulva japonica, was autoclaved at $121^{\circ} \mathrm{C}$ for $15 \mathrm{~min}$ with $1 \mathrm{l}$ of seawater passed through GF/F filters; (2) the autoclaved mixture was also passed through GF/F filters; (3) that filtrate was then centrifuged $(10000 \times g$ for $10 \mathrm{~min})$; and (4) the supernatant was passed through $0.2 \mu \mathrm{m}$ pore size filters (Anodisc, Whatman).

A $100 \mu \mathrm{l}$ aliquot of the seawater from Oura Bay and Nabeta Bay was added onto Marine Broth 2216 and the seaweed medium agar plates containing $1.5 \%$ of Bacto agar (Difco). The inoculated plates were incubated at $25^{\circ} \mathrm{C}$ in the dark for $1 \mathrm{wk}$. Randomly chosen colonies were selected from each plate and inoculated in Marine Broth 2216 liquid medium. These bacterial cultures were cultivated at $25^{\circ} \mathrm{C}$ in the dark with shaking (120 rotations $\mathrm{min}^{-1}$ ). The Roseobacter denitrificans Shiba, 1991 strain (accession number: L01784) was obtained from the Japan Collection of Microorganisms at the RIKEN Bio Resource Center (www.brc.riken.go.jp/inf/en/index.shtml) as one of the representative marine bacteria

\section{Extraction of nucleic acid and 16S rRNA gene analysis}

The cultures were centrifuged at $10000 \times g$ for $10 \mathrm{~min}$, and the supernatant was discarded to harvest bacterial cells. The nucleic acid from the harvested cells was extracted using a DNeasy tissue kit (Qiagen).

Polymerase chain reaction (PCR) amplification of bacterial 16S rRNA genes from DNA extracts was performed with the $27 \mathrm{f}\left(5^{\prime}\right.$-AGA GTT TGA TCM TGG CTC AG-3') (Lane 1991) and 1492r (5'-ACG GYT ACC TTG TTA CG-3') (Liu et al. 2001) primers.

Thermal cycling for the amplification was performed with a GeneAmp PCR system 9700 (Applied Biosystems) as follows: $10 \mathrm{~min}$ at $95^{\circ} \mathrm{C}, 30$ cycles of $30 \mathrm{~s}$ at $95^{\circ} \mathrm{C}, 30 \mathrm{~s}$ at $60^{\circ} \mathrm{C}$, and $1 \mathrm{~min}$ at $72^{\circ} \mathrm{C}$, followed by a final $7 \mathrm{~min}$ at $72^{\circ} \mathrm{C}$. The PCR products were purified using a QIAquick PCR product purification kit (Qiagen). The purified PCR products were sequenced on a CEQ2000 sequencer using a Dye Terminator Cycle sequencing kit (Beckman Coulter). The primers for the 16S rRNA gene sequence were 27f, 341f (5'-CCT ACG GGA GGC AGC AG-3') (Muyzer et al. 1993), 911r (5'-CCG TCA ATT CAT TTG AGT TT-3'), 1100r (5'-GGG TTG CGC TCG TTG-3') (Lane 1991) and 1492r. The nucleotide sequences of partial 16S rRNA genes were deposited in nucleotide sequence databases (DDBJ/EMBL/ GenBank) under the following accession numbers: AB378715-378718, AB378723, AB378724, AB496650, AB496653, AB496655 and AB496657.

The sequences were then analyzed with the Basic Local Alignment Search Tool (BLAST) and compared with those of environmental clones in available databases (DDBJ/EMBL/GenBank) to identify the nearest phylogenetic neighbors. All isolated bacterial strains used in the present experiment are listed in Table 1.

\section{Humic-like FDOM production experiment}

The artificial seawater was prepared by dissolving $35 \mathrm{~g}$ of sea salts (Sigma) in $1 \mathrm{l}$ of Milli-Q water. Marine Broth 2216 liquid medium was diluted 1:250 with the artificial seawater and passed through a $0.2 \mu \mathrm{m}$ pore size filter (Cyclopore track-etched membrane, Whatman) to remove particulate organic components. The final $100 \mathrm{ml}$ of filtrate was transferred into $200 \mathrm{ml}$ silicone-stoppered Erlenmeyer flasks and autoclaved at $121^{\circ} \mathrm{C}$ for $15 \mathrm{~min}$ for use as the experimental medium.

Bacterial strains were cultivated in the Marine Broth 2216 medium. Bacterial cultures were centrifuged at $10000 \times g$ for $10 \mathrm{~min}$, and the supernatant was discarded. The harvested cells were washed twice with, and resuspended in, sterile artificial seawater to prepare the bacterial inoculums for the experiment.

Four experimental media were prepared for each bacterial strain. The strain was only inoculated in 2 of the 4 experimental media. The experimental media that were not inoculated were treated as control samples. After inoculation, the cultures were immediately collected (Day 0 sample), and $80 \mathrm{ml}$ of the cultured samples were passed through a $0.2 \mu \mathrm{m}$ pore size filter (Anodisc, Whatman) to separate the organic matter into fractions of DOM (filtrate sample) and POM (filter sample). The remaining 2 cultures were kept at $20^{\circ} \mathrm{C}$ for $7 \mathrm{~d}$ in the dark without shaking. The samples were then recovered and treated like those of the Day 0 sample. The artificial seawater amended with Marine Broth 2216 liquid medium was also incubated without bacterial inoculum as a sterile control sample. 
Table 1. Bacterial strains isolated from coastal surface seawater. Nearest phylogenetic neighbors of isolated bacterial strains identified based on partial 16S rRNA gene analysis. MB: Marine Broth; Sm: seaweed medium; OB: Oura Bay; NB: Nabeta Bay

\begin{tabular}{|c|c|c|c|c|c|c|c|}
\hline $\begin{array}{l}\text { Strain } \\
\text { name }\end{array}$ & $\begin{array}{l}\text { Length } \\
\text { (bp) }\end{array}$ & $\begin{array}{l}\text { Accession } \\
\text { no. }\end{array}$ & $\begin{array}{l}\text { Closest phylogenetic neighbor } \\
\text { and accession no. }\end{array}$ & Classification & $\begin{array}{l}\text { Identity } \\
(\%)\end{array}$ & $\begin{array}{l}\text { Isolation } \\
\text { medium }\end{array}$ & $\begin{array}{l}\text { Isolation } \\
\text { source }\end{array}$ \\
\hline MB001 & 1337 & AB378716 & Sulfitobacter sp. JAM-AL10 [AB526332] & Alphaproteobacteria & 100 & MB 2216 & OB \\
\hline MB004 & 1399 & AB378718 & Alteromonas sp. H91 [FJ903194] & Gammaproteobacteria & 99 & MB 2216 & OB \\
\hline MB017 & 1386 & AB378723 & Thalassospira sp. MCCC 1A02898 [EU440835] & Alphaproteobacteria & 99 & MB 2216 & OB \\
\hline MB019 & 1417 & AB378724 & Pseudomonas stutzeri 13636M [EU741093] & Gammaproteobacteria & 99 & MB 2216 & OB \\
\hline Yb-D & 1413 & AB496653 & Marine bacterium Tw-9 [AY028204] & Gammaproteobacteria & 99 & $\mathrm{Sm}$ & NB \\
\hline $\mathrm{Yb}-\mathrm{F}$ & 1405 & AB496655 & Arcobacter sp. UDC316 [GQ245905] & Epsilonproteobacteria & 99 & $\mathrm{Sm}$ & NB \\
\hline Yb-I & 1431 & AB496657 & Vibrio penaeicida [AJ421444] & Gammaproteobacteria & 99 & $\mathrm{Sm}$ & NB \\
\hline
\end{tabular}

\section{Determination of DOC and POC concentrations}

The concentrations of DOC in the filtrate samples were measured using a high-temperature catalytic oxidation method (Sharp et al. 1993), using a total organic carbon analyzer (TOC-V, Shimadzu). The system was standardized before measurements with potassium hydrogen phthalate and the Hansell Laboratory Deep Seawater reference (Bermuda Biological Station for Research). The concentration of POC collected on an Anodisc filter was determined using an elemental analyzer (EA 1108, FISONS Instruments) according to Søndergaard \& Middelboe (1993), using glycine as a standard.

\section{UV-visible measurements}

UV-visible absorbance of the experimental samples was analyzed using a spectrophotometer (V-560 UV/VIS, Jasco) at wavelengths ranging from 200 to $550 \mathrm{~nm}$ in a $10 \times 10 \mathrm{~mm}$ quartz cell. Milli-Q water was used as a reference.

\section{Fluorescent properties}

The EEMs of DOM from the incubated sample were obtained using a spectrofluorometer (F-4500, Hitachi) in a $10 \times 10 \mathrm{~mm}$ quartz cell under the following conditions: scan ranges: 250 to $500 \mathrm{~nm}$ and 300 to $550 \mathrm{~nm}$ for excitation (Ex) and emission (Em), respectively; scan speed: $2400 \mathrm{~nm} \mathrm{~min}{ }^{-1}$; sampling interval: $5.0 \mathrm{~nm}$; Ex and Em slit width: $10 \mathrm{~nm}$; photomultiplier tube voltage: $700 \mathrm{~V}$ for EEM fluorescence of the incubation samples. Inner filter correction was carried out using the results of UV-visible measurements (Lakowicz 2006). We defined the Ex and Em light bandwidth as $5 \mathrm{~mm}$ by assuming that the fluorescence measurements were conducted in the middle of a $10 \times 10 \mathrm{~mm}$ quartz cell for the correction of the fluorescence intensity of the EEM. The corrected fluorescence intensity (CF) was calculated as follows:

$$
\mathrm{CF}=\mathrm{FI} \times 10^{-0.5(A \lambda \mathrm{Ex}+A \lambda \mathrm{Em})}
$$

where FI is the fluorescence intensity of the EEM at $\lambda \mathrm{Ex} / \lambda \mathrm{Em} \mathrm{nm}, A$ is absorbance, and $\lambda \mathrm{Ex}$ and $\lambda \mathrm{Em}$ are the Ex and Em wavelength, respectively. Fluorescence intensity was normalized to quinine sulfate units (QSU) (1 QSU $=1 \mathrm{\mu g} \mathrm{l}^{-1}$ quinine sulfate in $0.1 \mathrm{~mol} \mathrm{l}^{-1} \mathrm{H}_{2} \mathrm{SO}_{4}$ solution) (Coble 1996). The humiclike fluorescence peak in this experiment was defined as the peak detected within the ranges of 290 to $360 \mathrm{~nm}$ and 370 to $460 \mathrm{~nm}$ for Ex and Em, respectively (Coble 1996, Coble et al. 1998, Stedmon et al. 2003). The peak position in a sample was determined with visual inspection of the EEM and a calculation performed by a peak detection program handled with FL Solutions software (Hitachi).

\section{RESULTS}

\section{Isolation of bacterial strains}

The bacteria isolated from 2 different sampling sites and the results of a BLAST analysis of 16S rRNA genes are listed in Table 1. Eight strains belonged to different species, with the exceptions of MB002 and MB-F.

In general, the strains isolated using Marine Broth 2216 agar plates tended to be affiliated with Alphaproteobacteria and Gammaproteobacteria, while the 
strains isolated using seaweed agar plates were more likely to be related to Gammaproteobacteria and Epsilonproteobacteria.

\section{DOC and POC concentrations}

The changes in DOC and POC concentrations during the experiment are summarized in Table 2. The utilization of DOC varied among the bacterial strains. The decreases of DOC concentration during the experimental period varied from 63 to $436 \mu \mathrm{molC} \mathrm{l}^{-1}$ among the cultures. The DOC concentrations of the culture used to inoculate the MB004 strain declined from 858 to $422 \mu \mathrm{molC} \mathrm{l}^{-1}$ and showed the largest decrease among the strains. The smallest DOC decline $\left(63 \mu \mathrm{molC} \mathrm{l}^{-1}\right.$ ) was found in the $\mathrm{Yb}-\mathrm{F}$ culture. The decreasing DOC concentrations of the remaining 9 cultures varied from 86 to $237 \mu \mathrm{molC} \mathrm{l}^{-1}$. The DOC concentration of the control samples exhibited little change throughout the experiment.

All of the cultures showed an increase in the POC concentrations throughout the experiment. The POC concentrations of the cultures inoculated with the Yb-I and MB-F strains showed relatively greater

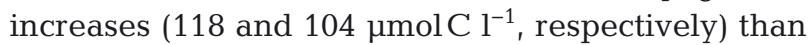
those in other cultures, while the smallest increase in POC was found in the Yb-D strain $\left(15 \mu \mathrm{molC} \mathrm{l}^{-1}\right)$. The POC concentration of the control samples showed little variation during the experiment. Because the POC concentration is considered to be an index of bacterial biomass, the ratio of an increase in the POC concentration $(\triangle \mathrm{POC})$ to the decrease in DOC concentration $(\triangle \mathrm{DOC})$ was calculated to esti- mate the difference in utilization of DOC among the bacterial strains. The $\triangle \mathrm{POC} / \triangle \mathrm{DOC}$ ratio varied from 0.12 to 0.89 ; the highest value was found in the $\mathrm{Yb}-\mathrm{F}$ strain, whereas the lowest was observed in the MB004 strain. Three of the 11 strains showed a bacterial growth efficiency of more than $60 \%$ in this experiment. Although these values are relatively high compared to those observed in oceanic environments (del Giorgio et al. 1997), growth efficiency sometimes exhibits high values $>60 \%$ in batch cultures (Bjørnsen 1986).

\section{Fluorescent properties of DOM}

Marine Broth 2216 has been widely used to isolate and cultivate marine bacterial strains. We selected this organic substrate as an experimental medium to research the many types of bacterial strains, even though this experimental medium has some methodological drawbacks.

The experimental medium without the bacterial inoculum (the control) had peaks centered at Ex/Em $=275 / 350$ and 320/400 nm (Fig. 1a). These peaks were derived from the compounds in Marine Broth 2216, and the presence of the fluorescence peaks in the culture medium might affect the interpretation of the experimental results. One of the possible effects is the difference in the fluorescence intensity among the experimental media. In the region of humic-like fluorescence $(\mathrm{Ex} / \mathrm{Em}=290$ to $360 / 370$ to $460 \mathrm{~nm})$, a slight variation in fluorescence intensity $<1.0$ QSU among the autoclaved experimental media without the bacterial inoculum was found before the incuba-

Table 2. Changes in dissolved (DOC) and particulate (POC) organic carbon concentration and $\triangle \mathrm{POC} / \triangle \mathrm{DOC}$ ratio. $\triangle \mathrm{DOC}$ : decrease in DOC concentration; $\triangle \mathrm{POC}$ : increase in POC concentration during the experiment

\begin{tabular}{|c|c|c|c|c|c|c|c|}
\hline \multirow[t]{2}{*}{$\begin{array}{l}\text { Strain } \\
\text { name }\end{array}$} & \multicolumn{2}{|c|}{ 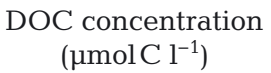 } & \multirow[t]{2}{*}{$\begin{array}{l}\text { DOC decrease } \\
\left(\mu \mathrm{mol} \mathrm{Cl}^{-1}\right)\end{array}$} & \multicolumn{2}{|c|}{$\begin{array}{c}\text { POC concentration } \\
\left(\mu \mathrm{mol} \mathrm{C}^{-1}\right)\end{array}$} & \multirow[t]{2}{*}{$\begin{array}{l}\text { POC increase } \\
\left(\mu \mathrm{molC} ~^{-1}\right)\end{array}$} & \multirow[t]{2}{*}{$\begin{array}{c}\Delta \mathrm{POC} / \Delta \mathrm{DOC} \\
\text { ratio }\end{array}$} \\
\hline & Day 0 & Day 7 & & Day 0 & Day 7 & & \\
\hline Control & 859 & 868 & -9 & 19.8 & 18.1 & -1.7 & - \\
\hline MB001 & 860 & 732 & 127 & 47.9 & 77.9 & 30.0 & 0.24 \\
\hline MB002 & 959 & 836 & 123 & 21.9 & 101.3 & 79.4 & 0.64 \\
\hline MB004 & 858 & 422 & 436 & 41.7 & 95.7 & 54.0 & 0.12 \\
\hline MB017 & 887 & 725 & 162 & 52.6 & 131.8 & 79.2 & 0.49 \\
\hline MB019 & 866 & 665 & 202 & 36.0 & 114.6 & 78.6 & 0.39 \\
\hline $\mathrm{MBF}$ & 952 & 783 & 169 & 21.9 & 125.9 & 104.0 & 0.61 \\
\hline $\mathrm{Yb}-\mathrm{A}$ & 943 & 857 & 86 & 22.4 & 66.6 & 44.3 & 0.52 \\
\hline Yb-D & 865 & 777 & 87 & 48.5 & 63.5 & 15.1 & 0.17 \\
\hline $\mathrm{Yb}-\mathrm{F}$ & 885 & 822 & 63 & 27.7 & 83.3 & 55.6 & 0.89 \\
\hline $\mathrm{Yb}-\mathrm{I}$ & 866 & 598 & 268 & 52.8 & 171.2 & 118.4 & 0.44 \\
\hline Roseobacter & 894 & 657 & 237 & 25.5 & 98.4 & 72.9 & 0.31 \\
\hline Bacterial assemblage & e 884 & 677 & 207 & 18.2 & 67.5 & 49.3 & 0.24 \\
\hline
\end{tabular}


a
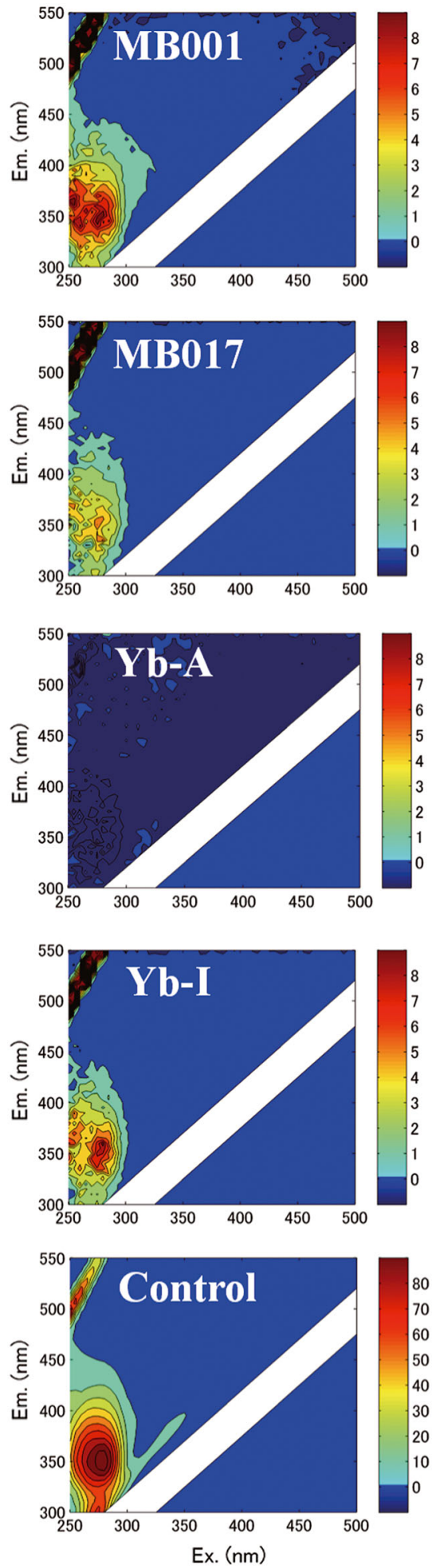
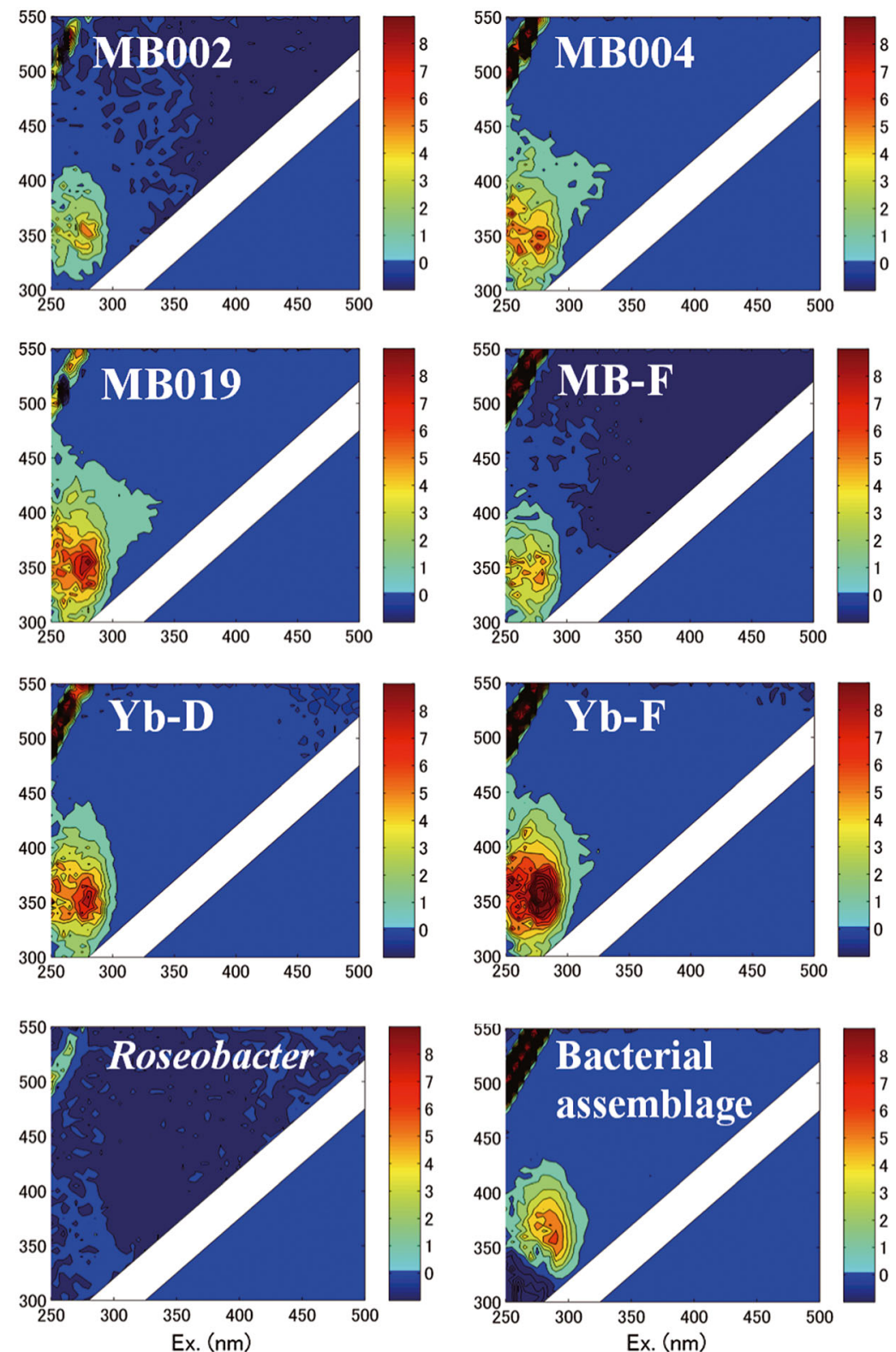

Fig. 1. Excitation (Ex.)-emission (Em.) matrices (EEMs) of incubated samples on (a) Day 0 and (b) Day 7. In the incubated samples, the EEM of the control sample of Days 0 or 7 was subtracted to eliminate the fluorescence of the control. Coloured bars are quinine sulfate units (QSU; 1 $\mathrm{QSU}=1 \mathrm{~g} \mathrm{l}^{-1}$ quinine sulfate in $0.1 \mathrm{~mol} \mathrm{l}^{-1} \mathrm{H}_{2} \mathrm{SO}_{4}$ ) Control (Day 7-0) means that the EEM of the control sample of Day 0 was subtracted from that of Day 7. Control shows the EEM of the culture medium (Marine Broth 2216) without any subtraction on Days 0 or 7 tion. A possible reason for this difference in the fluorescence intensity is the formation of tiny particles during autoclaving, which was observed after autoclaving. The difference in formation of the particles could affect the composition of Marine Broth 2216 and then cause the variation of fluorescence intensity among the media. However, the difference in the intensity was within 1.0 QSU among media. Another possible effect, which should be examined, is the abiotic alteration of the fluorescence during the experi- 
b
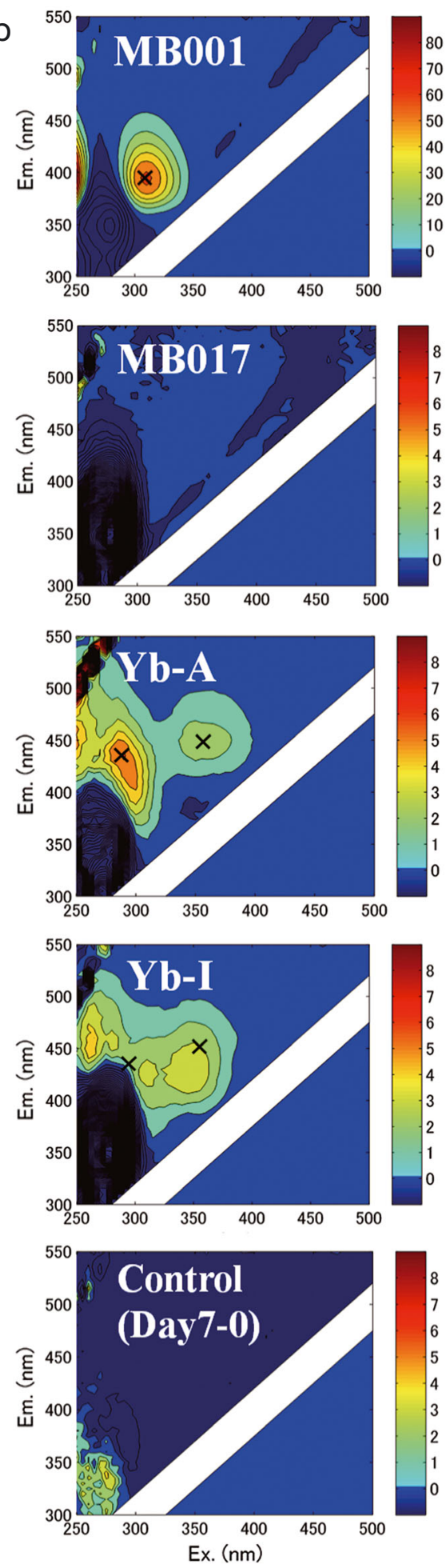
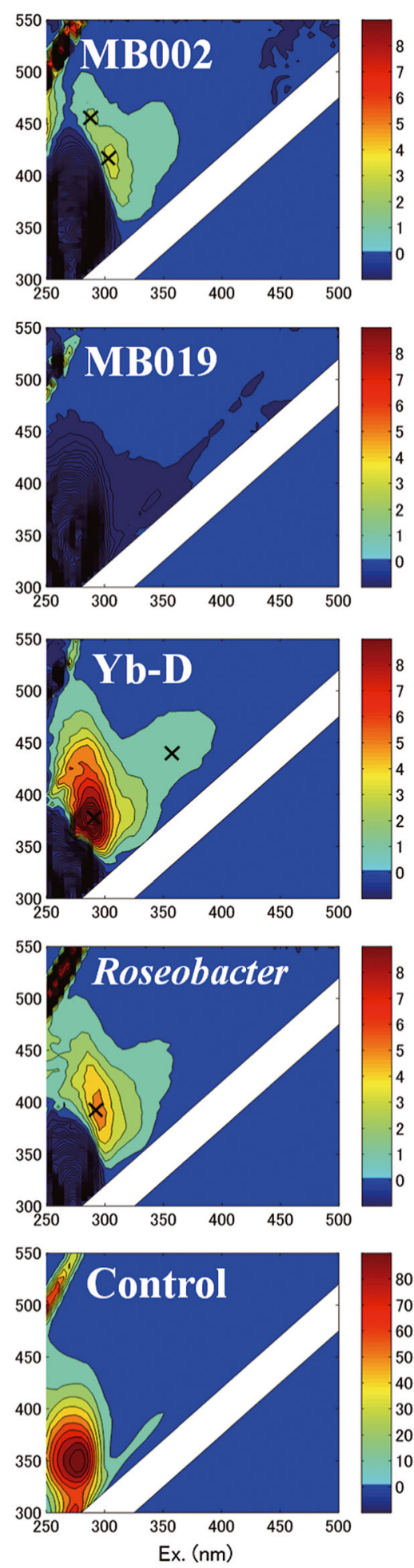
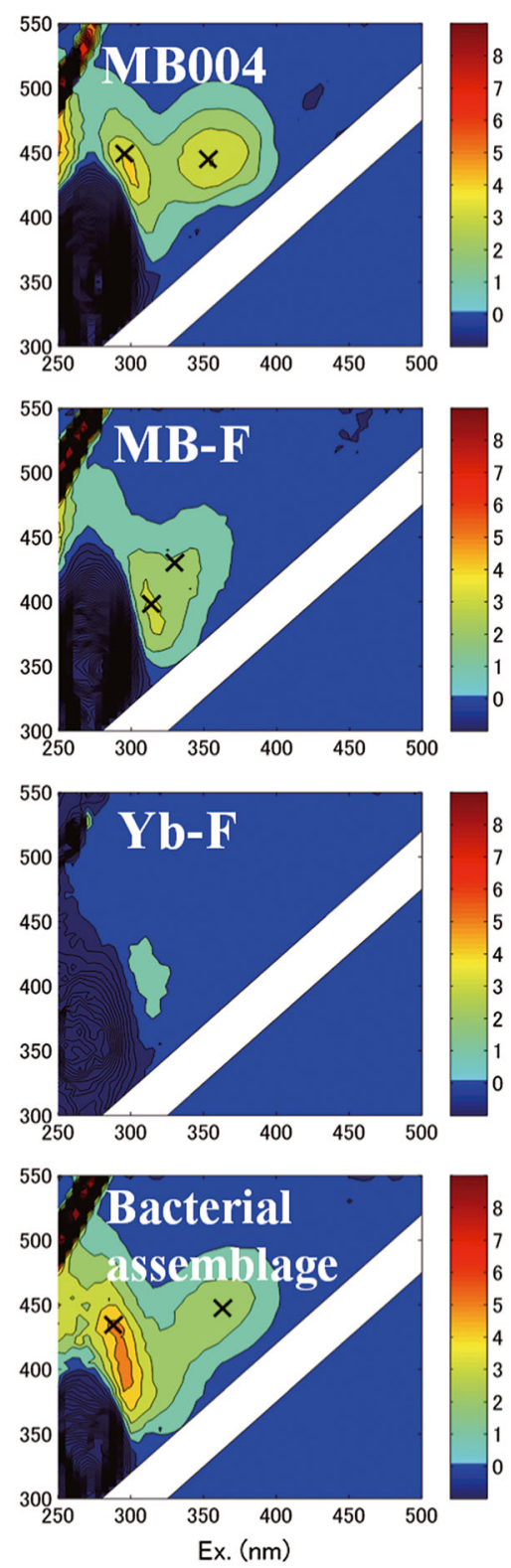

Fig. 1 (continued)

ment. Nevertheless, little change in the humic-like fluorescence intensity of control samples was observed during the incubation periods. This result shows that the abiotic alteration of the fluorescence is negligible.
The humic-like fluorescence intensity of incubated samples with bacterial inocula was changed by bacterial production of humic-like FDOM and compositional alteration of Marine Broth 2216 owing to bacterial consumption. The bacterial production and the 
compositional alteration resulted in an increase and decrease, respectively, in the humic-like fluorescence intensity. Considering these facts, we conclude that the increase in humic-like fluorescence intensity of >1.0 QSU on the EEM of the incubated samples, based on subtracting the result of Day 0 from that of Day 7 , was due to the bacterial production of humiclike FDOM.

In contrast, the EEM of the region around proteinlike fluorescence $(\mathrm{Ex} / \mathrm{Em}=275 / 305$ to $340 \mathrm{~nm})$ in the incubated sample was greatly affected by Marine Broth 2216. Although the abiotic change of protein-like fluorescence intensity was negligible in all cultures during the experimental period, the contribution of bacterial activity could not be estimated from the EEM. Thus, we consider only the fluorescence intensity of humic-like fluorescence in this study.

The EEM contour plots of the cultures on Days 0 and 7 were subtracted from that of each control sample (Fig. 1a,b). The peaks corresponding to humiclike fluorescence characteristics $(\mathrm{Ex} / \mathrm{Em}=290$ to 360 /370 to $460 \mathrm{~nm}$ ) are listed in Table 3. None of the Day 0 samples showed a humic-like fluorescence peak, with the exception of the peaks from Marine Broth 2216. On Day 7, the fluorescence peaks differed among cultured samples (Fig. 1b).
The culture media of the MB001 (Sulfitobacter) and Roseobacter denitrificans Shiba, 1991 strains exhibited a single peak. Two peaks were identified from the culture media of the MB002 (Thalassospira), MB004 (Alteromonas), MB-F (Thalassospira), Yb-A (Marinomonas), Yb-D (Marinomonas) and Yb-I (Vibrio) strains. The culture media of MB017 (Thalassospira), MB019 (Pseudomonas) and Yb-F (Arcobacter) did not show the humic-like fluorescence peaks. The medium from the culture of the Nabeta Bay bacterial assemblage showed 2 peaks. No additional fluorescence peaks were found in the control samples throughout the experiment. Common humic-like fluorescence peaks centered at Ex/Em $=355 / 445 \mathrm{~nm}$ were found for the MB004 and Yb-A strains. Another common peak, centered at Ex/Em = 290/435 nm, was detected between the $\mathrm{Yb}-\mathrm{A}$ and $\mathrm{Yb}$-I strains. A similar peak in the MB004 strain culture medium (Ex/Em $=355 / 445 \mathrm{~nm}$ ) was also found in both the Yb-D $(\mathrm{Ex} / \mathrm{Em}=360 / 440 \mathrm{~nm})$ and $\mathrm{Yb}-\mathrm{I}(\mathrm{Ex} / \mathrm{Em}=360 / 445 \mathrm{~nm})$ cultures. Another similarity was found between the MB001 (Ex/Em = 310/395 nm) and MB-F culture media $(E x / E m=315 / 390 \mathrm{~nm})$. The 2 peaks in the culture medium of the bacterial assemblage $(\mathrm{Ex} / \mathrm{Em}=$ 290/435 and 360/445 $\mathrm{nm}$ ) were consistent with peaks found in the $\mathrm{Yb}-\mathrm{A}(\mathrm{Ex} / \mathrm{Em}=290 / 435)$ and $\mathrm{Yb}-\mathrm{I}$ $(\mathrm{Ex} / \mathrm{Em}=290 / 435$ and 360/445 nm) culture media.

Table 3. Position of fluorescence peaks in excitation-emission matrices (EEMs) of bacterially derived humic-like FDOM, increase of quinine sulfate unit (QSU) intensity, $\triangle \mathrm{QSU} / \triangle \mathrm{POC}$ and $\Delta \mathrm{QSU} / \Delta \mathrm{DOC}$ in the experiment. $\Delta \mathrm{QSU}$ : respective increase in QSU intensity during the experiment; ND: not detected; NA: not available

\begin{tabular}{|c|c|c|c|c|}
\hline $\begin{array}{l}\text { Strain } \\
\text { name }\end{array}$ & $\begin{array}{l}\text { Peak position } \\
\text { (nm) }\end{array}$ & QSU increase & $\begin{array}{l}\Delta \mathrm{QSU} / \Delta \mathrm{POC} \text { ratio } \\
\left(\mathrm{QSU}\left[\mathrm{mmolC} \mathrm{l}^{-1}\right]^{-1}\right)\end{array}$ & $\begin{array}{l}\Delta \mathrm{QSU} / \Delta \mathrm{DOC} \text { ratio } \\
\left(\mathrm{QSU}\left[\mathrm{mmolC} \mathrm{l}^{-1}\right]^{-1}\right)\end{array}$ \\
\hline MB001 & $310 / 395$ & 61 & 2033 & 480 \\
\hline MB002 & $\begin{array}{l}290 / 455 \\
305 / 410\end{array}$ & $\begin{array}{l}2.5 \\
3.6\end{array}$ & $\begin{array}{l}31 \\
45\end{array}$ & $\begin{array}{l}20 \\
29\end{array}$ \\
\hline MB004 & $\begin{array}{l}295 / 450 \\
355 / 445\end{array}$ & $\begin{array}{l}3.6 \\
3.5\end{array}$ & $\begin{array}{l}67 \\
65\end{array}$ & $\begin{array}{l}8 \\
8\end{array}$ \\
\hline MB017 & ND & NA & NA & NA \\
\hline MB019 & ND & NA & NA & NA \\
\hline MB-F & $\begin{array}{l}315 / 390 \\
335 / 435\end{array}$ & $\begin{array}{l}3.5 \\
2.3\end{array}$ & $\begin{array}{l}34 \\
22\end{array}$ & $\begin{array}{l}21 \\
14\end{array}$ \\
\hline $\mathrm{Yb}-\mathrm{A}$ & $\begin{array}{l}290 / 435 \\
355 / 445\end{array}$ & $\begin{array}{l}6.9 \\
2.6\end{array}$ & $\begin{array}{c}157 \\
59\end{array}$ & $\begin{array}{l}81 \\
30\end{array}$ \\
\hline Yb-D & $\begin{array}{l}290 / 375 \\
360 / 440\end{array}$ & $\begin{array}{l}10 \\
1.5\end{array}$ & $\begin{array}{c}667 \\
97\end{array}$ & $\begin{array}{c}115 \\
17\end{array}$ \\
\hline $\mathrm{Yb}-\mathrm{F}$ & ND & NA & NA & NA \\
\hline $\mathrm{Yb}-\mathrm{I}$ & $\begin{array}{l}290 / 435 \\
360 / 445\end{array}$ & $\begin{array}{l}3.5 \\
2.9\end{array}$ & $\begin{array}{l}30 \\
25\end{array}$ & $\begin{array}{l}13 \\
11\end{array}$ \\
\hline Roseobacter & $295 / 390$ & 6.0 & 83 & 25 \\
\hline Bacterial assemblage & $\begin{array}{l}290 / 435 \\
360 / 445\end{array}$ & $\begin{array}{l}4.6 \\
2.5\end{array}$ & $\begin{array}{l}93 \\
51\end{array}$ & $\begin{array}{l}22 \\
12\end{array}$ \\
\hline
\end{tabular}




\section{QSU/DOC and QSU/POC ratios}

The maximum peak positions and QSU intensity shown in Table 3 differed among the strains. The culture medium of the MB001 strain displayed the strongest peak at Ex/Em $=310 / 395 \mathrm{~nm}$ and evidenced the highest increase in the QSU intensity $(\triangle \mathrm{QSU}) / \triangle \mathrm{POC}$ (QSU $\left[\mathrm{mmolC} \mathrm{l}^{-1}\right]^{-1}$ ) ratio (2033) among the strains used in this experiment. Relatively high $\triangle \mathrm{QSU} / \triangle \mathrm{POC}$ ratios were found in the culture media of the Yb-A and Yb-D strains, i.e. 157 and 667, respectively. Among the remaining cultures, the $\triangle \mathrm{QSU} / \triangle \mathrm{POC}$ ratio was $<98$. The medium from the MB001 strain also exhibited the highest $\triangle$ QSU/ $\triangle \mathrm{DOC}\left(\mathrm{QSU}\left[\mathrm{mmolC} \mathrm{l}^{-1}\right]^{-1}\right.$ ) ratio (480), while the $\triangle \mathrm{QSU} / \triangle \mathrm{DOC}$ ratios of the rest of the cultures were $<30$, except for the medium from the $\mathrm{Yb}-\mathrm{A}$ and $\mathrm{Yb}-\mathrm{D}$ strain cultures, which represented relatively higher $\triangle \mathrm{QSU} / \triangle \mathrm{POC}$ ratios (81 and 115).

\section{DISCUSSION}

FDOM is commonly observed in the ocean, and the difference in its fluorescence characteristics reflects its origin. Fluorescence characteristics of FDOM can be often utilized for tracing the influence of allochthonous DOM in coastal regions (Stedmon \& Markager 2005, Murphy et al. 2008). Autochthonous humic-like FDOM also has fluorescence variations. Some researchers experimentally demonstrated the microbial production of FDOM (e.g. Kramer \& Herndl 2004) and fluorescence characteristics of autochthonous humic-like FDOM (Shimotori et al.
2009). However, variation of fluorescence characteristics of autochthonous humic-like FDOM produced by individual bacterial strains is poorly understood.

In this study, a total of 14 humic-like fluorescence peaks were detected in 8 of 11 bacterial cultures (Fig. 1b, Table 3), and those fluorescence characteristics were comparable to the marine and visible humic-like fluorescence characteristics that were defined by Coble et al. (1998). This result implies that many bacterial phylogenetic groups produce humiclike FDOM, and this is one of the reasons why humiclike FDOM is commonly observed in oceanic environments. When we focus on the detailed difference in the fluorescence peaks, however, various peaks with wavelengths different from the representative one were found. The Ex/Em pairs of the 10 humiclike fluorescence peaks were different, clearly demonstrating that the fluorescence characteristics of BAC-humic- like FDOM differ among bacterial genera.

The variety in the fluorescence characteristics of BAC-humic-like FDOM is a notable finding for understanding the source of humic-like FDOM observed in the oceanic environment. Humic-like FDOM generally has different fluorescence peaks depending on the origins of production (Table 4). In coastal regions, a negative correlation is often found between the fluorescence intensity of terrestrial humic-like FDOM and salinity, suggesting that the humic-like FDOM concentration is significantly influenced by terrestrial humic-like FDOM inputs (Blough \& Del Vecchio 2002). Therefore, it seems reasonable to use fluorescence characteristics to trace the terrestrial components of DOM. However,

Table 4. Position of fluorescence maxima of components of excitation-emission matrices identified in previous studies. Wave lengths in brackets represent secondary maxima. Ex/Em: excitation/emission wavelengths (nm)

\begin{tabular}{|c|c|c|c|c|}
\hline Description & $\begin{array}{l}\text { Microbial (autochtho- } \\
\text { nous) origin (Ex/Em) }\end{array}$ & $\begin{array}{c}\text { Terrestrial } \\
\text { origin }(E x / E m)\end{array}$ & $\begin{array}{l}\text { Associated with phytoplank- } \\
\text { ton productivity (Ex/Em) }\end{array}$ & $\begin{array}{c}\text { Origin un- } \\
\text { certain }(\mathrm{Ex} / \mathrm{Em})\end{array}$ \\
\hline $\begin{array}{l}\text { Visible marine humic-like (M) } \\
(\mathrm{Ex} / \mathrm{Em}=290-310 / 370-410)^{\mathrm{a}}\end{array}$ & $\begin{array}{c}295 / 398^{\mathrm{c}} \\
315 / 418^{\mathrm{d}} \\
325(275) / 385^{\mathrm{e}}\end{array}$ & $\begin{array}{c}325(250) / 416^{\mathrm{b}} \\
315 / 418^{\mathrm{d}}\end{array}$ & & \\
\hline $\begin{array}{l}\text { Visible humic-like }(\mathrm{C}) \\
(\mathrm{Ex} / \mathrm{Em}=320-360 / 420-460)^{\mathrm{a}}\end{array}$ & $345 / 434^{\mathrm{c}}$ & $\begin{array}{c}270(360) / 478^{\mathrm{b}} \\
260(370) / 490^{\mathrm{d}} \\
250(380) / 434^{\mathrm{d}} \\
345 / 433^{\mathrm{e}}\end{array}$ & & \\
\hline Humic-like & $420(275) / 488^{\mathrm{c}}$ & $390(275) / 479^{\mathrm{e}}$ & & \\
\hline $\begin{array}{l}\text { Unknown (N) } \\
(\text { Ex/Em }=280 / 370)^{\mathrm{a}}\end{array}$ & $285 / 362^{\mathrm{e}}$ & & $280(<240) / 368^{\mathrm{b}}$ & $250(320) / 370^{\mathrm{d}}$ \\
\hline
\end{tabular}


our results showed that some humic-like FDOM components that have similar humic-like fluorescence to that associated with a terrestrial origin are produced in situ by bacterial activity. The culturing media of the MB001, MB002, MB-F, Yb-A and Roseobacter denitrificans Shiba, 1991 strains exhibited a marine humic-like fluorescence (Fig. 1b, Table 3), while the MB004, Yb-A, Yb-D,Yb-I and bacterial assemblage had peaks that were comparable to humic-like fluorescence associated with terrestrial origins (Fig. 1b, Tables 3 and 4). These results suggest that humiclike FDOM apparently associated with terrestrial origins is instead produced autochthonously by bacteria in coastal environments. This possibility is supported by a recent report that a humic-like fluorophore, which has been considered to have a terrestrial origin, was found as a constituent of FDOM in seawater in the bathypelagic layer (Yamashita et al. 2010). This finding also reveals that the traditional estimation of the source of FDOM in coastal regions based on fluorescence characteristics involves uncertainty; part of the FDOM, which had previously been regarded as 'terrestrial', can be produced in situ by marine bacteria.

In a coastal region, several fluorescence characteristics of autochthonous FDOM have been reported (Table 4). Several factors have been proposed, such as photochemical reactions (Vähätalo \& Wetzel 2004) and differences in microbial sources (Stedmon et al. 2003). Our results indicate that the difference in bacterial community structures may explain the variation in fluorescence characteristics of autochthonous FDOM. Because the bacterial strains used in this experiment were isolated from coastal regions, it is possible that their production of humic-like FDOM occurred in the coastal ocean. Thus, the difference in fluorescence characteristics of BAC-humic-like FDOM might explain the variability of fluorescence characteristics of autochthonous FDOM observed in coastal environments. However, most marine bacterial species are uncultivable, which limits the availability of isolated bacterial strains for use in experiments. Hence, the present results are not enough to clarify which bacterial phylogenetic groups are important for the distribution of oceanic FDOM. Therefore, it is advisable to consider bacterial community structures to elucidate the relationship between the distribution of humic-like FDOM and its fluorescence characteristics.

The difference in humic-like FDOM productivity among bacterial groups is also an important finding in our study. There are a large number of bacterial species in the ocean, and their individual metabo- lisms differ (Nealson 1999). Several bacterial groups, such as SAR11 and Roseobacter, quantitatively dominate the oceanic bacterial community (Giovannoni \& Rappé 2000). Thus, if bacteria are the dominant source of humic-like FDOM in the ocean, the humiclike FDOM productivity and quality might be dominated by the most abundant bacterial groups. However, no information is available about the quantitative contribution of each bacterial phylogenetic group to the oceanic humic-like FDOM pool. Our results indicate that specific bacterial genera might play an important role from the standpoint of humiclike FDOM production, even though the relative abundance of such genera may be lower than that of other bacterial groups in the ocean.

$\triangle \mathrm{QSU} / \triangle \mathrm{POC}$ and $\Delta \mathrm{QSU} / \triangle \mathrm{DOC}$ ratios indicate the capacity of humic-like FDOM production by bacterial strains. Considerable variations of both ratios were found among bacterial strains, suggesting that humic-like FDOM production ability differed among bacterial groups. In the present study, in particular, the MB001 strain, which is phylogenetically closely related to the genus Sulfitobacter, a well-isolated bacterial group in oceanic environments (Prabagaran et al. 2007, Stevens \& Ulloa 2008), showed a 10-fold higher humic-like FDOM production than the other strains. These findings imply that a specific bacterial group, such as the MB001 strain, with high humiclike FDOM productivity might play an important role in local humic-like FDOM production and diversity. Although the reason for this difference is currently not clear, it may be partly due to the difference in DOM utilization ability of each bacterial strain. Several studies have shown that the utilization of dissolved organic components by bacteria differs across major phylogenetic groups (Cottrell \& Kirchman 2000, Alonso \& Pernthaler 2006). As for the utilization of DOM, it is conceivable that the relative contribution to humic-like FDOM production by bacteria may differ among bacterial phylogenetic groups in the ocean. Therefore, the relationships among the quality of DOM, humic-like FDOM productivity and bacterial phylogenetic groups need to be examined in further studies to elucidate the precise production mechanism of FDOM.

Acknowledgements. We thank the members of the Ibaraki Kasumigaura Environmental Science Center for their kind cooperation and the members of the Shimoda Marine Research Center, University of Tsukuba, for their generous assistance in the water sample collection. We are grateful to Namiha Yamada for her helpful guidance on the bacterial isolation procedure. We thank the Chemical Analysis Center, University of Tsukuba, for the use of their spectrofluo- 
rometer. This work was supported by grants from the Ministry of Education, Culture, Sports, Science and Technology, Japan (nos. 14340166 and 19310003), the Sasakawa Scientific Research Grant, the Japan Science Society, and the Steel Industry Foundation for the Advancement of Environmental Protection Technology.

\section{LITERATURE CITED}

Alonso C, Pernthaler J (2006) Roseobacter and SAR11 dominate microbial glucose uptake in coastal North Sea waters. Environ Microbiol 8:2022-2030

Benner R (2002) Chemical composition and reactivity. In: Hansell AD, Carlson CA (eds) Biogeochemistry of marine dissolved organic matter. Academic Press, San Diego, CA, p 59-90

Bertilsson S, Jones JB (2003) Supply of dissolved organic matter to aquatic ecosystems: autochthonous sources. In: Findlay SEG, Sinsabaugh RL (eds) Aquatic ecosystems interactivity of dissolved organic matter. Academic Press, San Diego, CA, p 3-24

Bjørnsen PK (1986) Bacterioplankton growth yield in continuous seawater cultures. Mar Ecol Prog Ser 30:191-196

Blough NV, Del Vecchio R (2002) Chromophoric DOM in the coastal environment. In: Hansell AD, Carlson CA (eds) Biogeochemistry of marine dissolved organic matter. Academic Press, San Diego, CAp 509-546

Carlson CA (2002) Production and removal processes. In: Hansell AD, Carlson CA (eds) Biogeochemistry of marine dissolved organic matter. Academic Press, San Diego, CA, p 91-151

> Coble PG (1996) Characterization of marine and terrestrial DOM in seawater using excitation-emission matrix spectroscopy. Mar Chem 51:325-346

Coble PG, Del Castillo CE, Avril B (1998) Distribution and optical properties of CDOM in the Arabian Sea during the 1995 Southwest Monsoon. Deep-Sea Res II 45:2195-2223

Cottrell MT, Kirchman DL (2000) Natural assemblages of marine proteobacteria and members of the CytophagaFlavobacter cluster consuming low- and high-molecularweight dissolved organic matter. Appl Environ Microbiol 66:1692-1697

del Giorgio PA, Cole JJ, Cimbleris A (1997) Respiration rates in bacteria exceed phytoplankton production in unproductive aquatic systems. Nature 385:148-151

Giovannoni SJ, Rappé MS (2000) Evolution, diversity, and molecular ecology of marine prokaryotes. In: Kirchman DL (ed) Microbial ecology of the oceans. Wiley-Liss, New York, NY, p 47-84

> Hama T, Yanagi K, Hama J (2004) Decrease in molecular weight of photosynthetic products of marine phytoplankton during early diagenesis. Limnol Oceanogr 49: $471-481$

> Hayase K, Shinozuka N (1995) Vertical distribution of fluorescent organic matter along with $\mathrm{AOU}$ and nutrients in the equatorial Central Pacific. Mar Chem 48:283-290

> Hedges JI (1992) Global biogeochemical cycles: progress and problems. Mar Chem 39:67-93

Kramer GD, Herndl GJ (2004) Photo- and bioreactivity of chromophoric dissolved organic matter produced by marine bacterioplankton. Aquat Microb Ecol 36:239-246

Lakowicz JR (2006) Principles of Fluorescence Spectroscopy, 3rd edn. Springer Science \& Business, New York, NY
Lane DJ (1991) 16S/23S rRNA sequencing. In: Stackebrandt E, Goodfellow M (eds) Nucleic acid techniques in bacterial systematics. John Wiley \& Sons, New York, NY, p 115-175

Liu WT, Mirzabekov AD, Stahl DA (2001) Optimization of an oligonucleotide microchip for microbial identification studies: a non-equilibrium dissociation approach. Environ Microbiol 3:619-629

Mopper K, Stubbins A, Ritchie JD, Bialk HM, Hatcher PG (2007) Advanced instrumental approaches for characterization of marine dissolved organic matter: extraction techniques, mass spectrometry, and nuclear magnetic resonance spectroscopy. Chem Rev 107:419-442

Moran MA, Sheldon W, Zepp RG (2000) Carbon loss and optical property changes during long-term photochemical and biological degradation of estuarine dissolved organic matter. Limnol Oceanogr 45:1254-1264

> Murphy KR, Stedmon CA, Waite TD, Ruiz GM (2008) Distinguishing between terrestrial and autochthonous organic matter sources in marine environments using fluorescence spectroscopy. Mar Chem 108:40-58

> Muyzer G, de Waal EC, Uitterlinden AG (1993) Profiling of complex microbial populations by denaturing gradient gel electrophoresis analysis of polymerase chain reaction-amplified genes coding for 16S rRNA. Appl Environ Microbiol 59:695-700

> Nealson KH (1999) Post-Viking microbiology: new approaches, new data, new insights. Orig Life Evol Biosph 29:73-93

Obernosterer I, Reitner B, Herndl GJ (1999) Contrasting effects of solar radiation on dissolved organic matter and its bioavailability to marine bacterioplankton. Limnol Oceanogr 44:1645-1654

Ogawa H, Amagai Y, Koike I, Kaiser K, Benner R (2001) Production of refractory dissolved organic matter by bacteria. Science 292:917-920

Parlanti E, Worz K, Geoffroy L, Lamotte M (2000) Dissolved organic matter fluorescence spectroscopy as a tool to estimate biological activity in a coastal zone submitted to anthropogenic inputs. Org Geochem 31:1765-1781

> Prabagaran SR, Manorama R, Delille D, Shivaji S (2007) Predominance of Roseobacter, Sulfitobacter, Glaciecola and Psychrobacter in seawater collected off Ushuaia, Argentina, Sub-Antarctica. FEMS Microbiol Ecol 59: 342-355

> Sharp JH, Peltzer ET, Alperin MJ, Cauwet G and 7 others (1993) Procedures subgroup report. Mar Chem 41:37-49

> Shimotori K, Omori Y, Hama T (2009) Bacterial production of marine humic-like fluorescent dissolved organic matter and its biogeochemical importance. Aquat Microb Ecol 58:55-66

Søndergaard M, Middelboe M (1993) Measurements of particulate organic carbon: a note on the use of glass fiber (GF/F) and Anodisc filters. Arch Hydrobiol 127:73-85

Stedmon CA, Markager S (2005) Tracing the production and degradation of autochthonous fractions of dissolved organic matter by fluorescence analysis. Limnol Oceanogr 50:1415-1426

Stedmon CA, Markager S, Bro R (2003) Tracing dissolved organic matter in aquatic environments using a new approach to fluorescence spectroscopy. Mar Chem 82: 239-254

Stevens H, Ulloa O (2008) Bacterial diversity in the oxygen minimum zone of the eastern tropical South Pacific. Environ Microbiol 10:1244-1259 
Vähätalo AV, Wetzel RG (2004) Photochemical and microbial decomposition of chromophoric dissolved organic matter during long (months-years) exposures. Mar Chem 89:313-326

Williams PM, Druffel ERM (1987) Radiocarbon in dissolved organic matter in the central North Pacific Ocean. Nature 330: 246-248

Yamashita Y, Tanoue E (2004) In situ production of chromophoric dissolved organic matter in coastal environments. Geophys Res Lett 31,L14302, doi:10.1029/ 2004GL019734

Yamashita Y, Tanoue E (2008) Production of bio-refractory fluorescent dissolved organic matter in the ocean interior. Nat Geosci 1:579-582

Editorial responsibility: Lars Tranvik, Uppsala, Sweden
Yamashita Y, Tsukasaki A, Nishida T, Tanoue E (2007) Vertical and horizontal distribution of fluorescent dissolved organic matter in the Southern Ocean. Mar Chem 106: 498-509

Yamashita Y, Jaffé R, Maie N, Tanoue E (2008) Assessing the dynamics of dissolved organic matter (DOM) in coastal environments by excitation emission matrix fluorescence and parallel factor analysis (EEM-PARAFAC). Limnol Oceanogr 53:1900-1908

Yamashita Y, Cory RM, Nishioka J, Kuma K, Tanoue E, Jaffé $R$ (2010) Fluorescence characteristics of dissolved organic matter in the deep waters of the Okhotsk Sea and the northwestern North Pacific Ocean. Deep-Sea Res II 57:1478-1485

Submitted: January 26, 2011; Accepted: January 7, 2012 Proofs received from author(s): February 21, 2012 